R.W.M. Wahba MB BCh MSc FRCPC, M.J. Tessler MD FRCPC, F. Béïque MD FRCPC, S.J. Kleiman MD FRCPC

\section{Changes in $\mathrm{PCO}_{2}$ with acute changes in cardiac index}

diats des altérations de l'IC sur la $\mathrm{PaCO}_{2}$, la $\mathrm{PETCO}_{2}$ et par conséquent de la différence $\mathrm{Pa}-\mathrm{PETCO}_{2}$.

Méthodes: Les auteurs ont mesurés l'IC, la Pa et PETCO $\mathrm{O}_{2}$ et en ont calculé la différence chez 20 patients programmés pour une chirurgie cardiaque non urgente avant et immédiatement après la sternotomie. Les mesures ont été réalisées selon les méthodes standards: la thermodilution pour l'IC, l'analyse aux infrarouges pour la $\mathrm{PETCO}_{2}$ et des gaz artériels pour $\mathrm{PaCO}_{2}$. Les résultats ont été analysés par régression linéaire.

Résultats: Des changements importants, directs et immédiats de PET et $\mathrm{PaCO}_{2}$ ont été notés avec les changements de l'IC. Les ratios étaient respectivement de 3,8 et $4,2 \mathrm{mmHg} \mathrm{L^{-1 }}$. Les valeurs calculées de $r$ étaient de $0,75(P<0,001)$ pour la $\mathrm{PETCO}_{2}$ et de 0,74 $(\mathrm{P}<0,005)$ pour la $\mathrm{PaCO}_{2}$. L'ordre de grandeur des changements individuels de $\mathrm{PCO}_{2}$ a varié considérablement de sorte que les altérations de la différence $\mathrm{Pa}-\mathrm{PETCO}_{2}$ ont aussi fluctué sans corrélation avec la direction ou l'importance des changements de l'IC.

Conclusions: Ces résultats expliquent la grande variabilité de $\mathrm{Pa}-\mathrm{PETCO}_{2}$ qui accompagnent les perturbations de l'IC. Ces observations ne s'appliquent qu'à un état d'instabilité. Les résultats suggèrent que la PETCO $\mathrm{CO}_{2}$ peut être utilisée avec une degré de confiance raisonnable pour évaluer les changements de l'IC.

Continuous end-tidal $\mathrm{CO}_{2}$ tension $\left(\mathrm{PETCO}_{2}\right)$ measurements during steady state anaesthesia reliably estimate arterial $\mathrm{PCO}_{2}\left(\mathrm{PaCO}_{2}\right)$. Thus the $\mathrm{Pa}-\mathrm{PETCO}_{2}$ gradient will not change when ventilation, cardiac output and $\mathrm{CO}_{2}$ production are constant. ${ }^{1}$ The considerable changes in cardiac index (CI) during major vascular surgery cause marked variations in the $\mathrm{Pa}-\mathrm{PETCO}_{2}$ difference. ${ }^{2}$ A direct relationship between $\mathrm{CI}$ and $\mathrm{PETCO}_{2}$ during aortic surgery has been reported recently. ${ }^{3}$ The authors, however, did not measure the simultaneous changes in arterial $\mathrm{PCO}_{2}$. The immediate influence of acute changes in $\mathrm{CI}$ on $\mathrm{PaCO}_{2}$ and $\mathrm{Pa}-\mathrm{PETCO}_{2}$ is thus not known. The purpose of our study was to provide that information.

\section{Methods}

The study was approved by the Research and Ethics Committee of our hospital. The sample consisted of 20 
ASA 3-4 adults undergoing elective coronary artery bypass grafting (CABG), some with valve replacement. The age range was from 44 to $79 \mathrm{yr}$ and the weights and heights ranged from 64 to $90 \mathrm{~kg}$ and 156 to $175 \mathrm{~cm}$ respectively.

The premedication and the anaesthetic agents used were at the individual anaesthetist's discretion but consisted of opioids (fentanyl or sufentanil) by $i v$ infusion or intermittent injection and isoflurane in $\mathrm{O}_{2}$ enriched air, supplemented by major tranquilizers and muscle relaxants to facilitate controlled ventilation. The lungs were ventilated at $10 \mathrm{ml} \cdot \mathrm{kg}^{-1}$ at $10 \mathrm{~b} \cdot \mathrm{min}^{-1}$. Venous, arterial and pulmonary artery catheters were inserted percutaneously.

The measurements were made at two specific points: just before and immediately after sternotomy because of the expected intensity of the surgical stimulus. Cardiac index was measured by thermodilution in triplicate and arterial and mixed venous blood were sampled for immediate analysis of $\mathrm{PCO}_{2}$ by a GEM "premier" (Mallinckrodt ${ }^{\circledR}$ ) analyzer. This analyzer is calibrated every morning for $\mathrm{CO}_{2}$ tensions in the range of 35 to 79 $\mathrm{mmHg}$ and is then recalibrated automatically every 20 min. End-tidal $\mathrm{PCO}_{2}$ was measured by a HewlettPackard ${ }^{\circledR}$ infra red $\mathrm{CO}_{2}$ analyzer attached to the proximal end of the tracheal tube. The analyzer is calibrated daily in the range of 0 to $55 \mathrm{mmHg}$. During the withdrawal of the blood samples, the mean of three consecutive $\mathrm{PETCO} \mathrm{C}_{2}$ s was calculated and recorded.

The data were analyzed by least squares linear regression using a commercial statistical package (Instat 2). A $P$ value $<0.05$ was considered significant.

\section{Results}

Cardiac index increased in seven patients, decreased in 11 , and was unchanged in two patients. In almost all instances, $\mathrm{Pa}$ and $\mathrm{PETCO}_{2}$ changed in the same direction as $\mathrm{CI}$. The magnitude of $\mathrm{PCO}_{2}$ change was variable. The range of change $(\Delta$ in $\mathrm{CI}$ was -1.0 to $+1.0 \mathrm{~L}$. Figure 1 shows the individual changes in $\mathrm{PETCO}_{2}$ and in $\mathrm{PaCO}_{2}$ versus $\triangle \mathrm{CI}$. The lines of best fit are also shown. A significant relationship was found in the case of $\mathrm{Pa}$ and $\mathrm{PETCO}_{2}$ but not in the case of mixed venous $\mathrm{PCO}_{2}$. The slopes of arterial and end-tidal $\mathrm{PCO}_{2}$ were close (3.83 vs $\left.4.24 \mathrm{~L} \cdot \mathrm{mmHg}^{-1}\right)$, but not parallel. There was marked individual variation in $\mathrm{Pa}$ and $\mathrm{PETCO}_{2}$, such that the difference also changed variably (Figure 2). There were no negative $\mathrm{Pa}-\mathrm{PETCO} \mathrm{C}_{2}$.

The results of the regression analysis are shown in the Table.

\section{Discussion}

We report direct and immediate changes in PET and

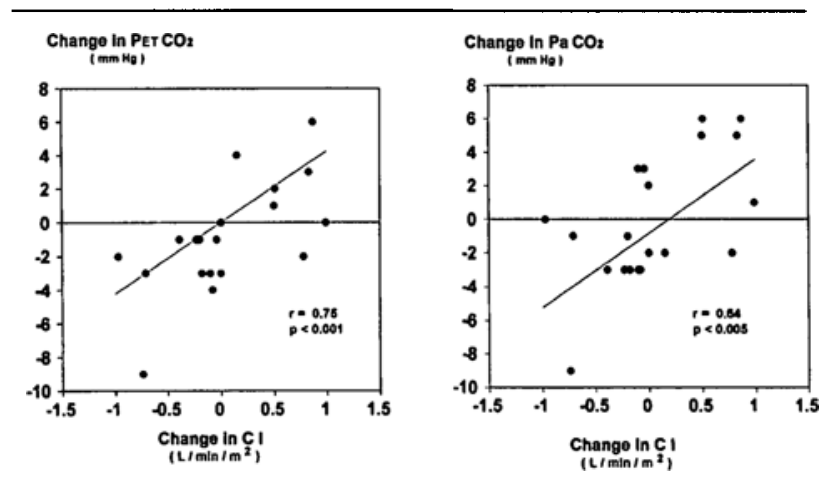

FIGURE 1 Change in $\mathrm{Pa}$ and $\mathrm{PETCO}_{2}$ with change in Cardiac Index.

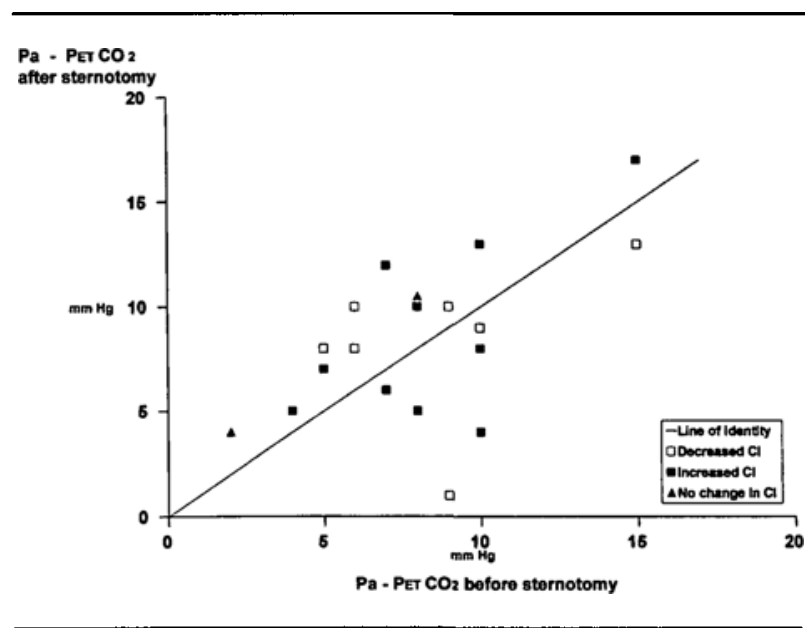

FIGURE 2 Arterial: end-tidal $\mathrm{PCO}_{2}$ gradient.

$\mathrm{PaCO}_{2}$ with changes in $\mathrm{CI}$ (Figure 1), without significant changes in mixed venous $\mathrm{PCO}_{2}$. These observations were made during increases and decreases in CI. We also found that the changes in $\mathrm{Pa}-\mathrm{PETCO}_{2}$ difference were variable in direction and magnitude and that the direction was not related to the direction of change in CI (Figure 2).

We anticipated that sternotomy would increase $\mathrm{CI}$. The fact that $\mathrm{CI}$ decreased in 11 patients suggests that anaesthesia was deeper than the usual clinical signs, blood pressure and heart rate, indicated. It is also possible that in some instances the greatly increased afterload may have prevented the expected increase in CI from occurring.

We report a $3.8 \mathrm{mmHg}$ change in $\mathrm{PeTCO}_{2}$ per litre change in $\mathrm{CI}$. This ratio is similar to the reported 3-4 $\mathrm{mmHg}$ per litre change with reduced $\mathrm{CI}$ during abdominal aortic aneurysmectomy (AAA) ${ }^{3}$ and $\mathrm{CABG}^{4}$ In both reports, the direct relationship was also statistically significant ( $r=0.82$ and 0.87 respectively). Thus a knowledge of changes in $\mathrm{PETCO}_{2}$ alone can give a use- 
TABLE

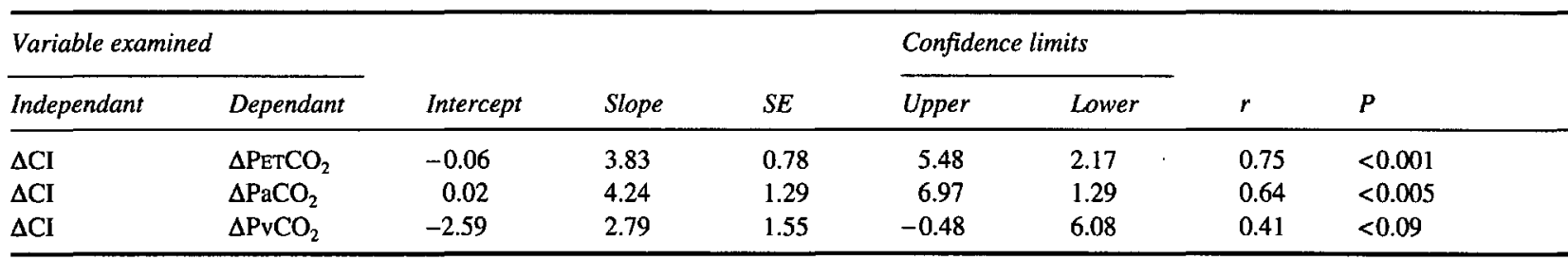

ful estimate of changes in cardiac index, assuming that metabolism and alveolar ventilation are unchanged.

We are unaware of studies presenting data on $\mathrm{Pa}$ and $\mathrm{PETCO}_{2}$. The fact that there was variability in the $\mathrm{Pa}-\mathrm{PETCO}_{2}$ difference and that mixed venous $\mathrm{PCO}_{2}$ did not change are probably due to the unsteady state at the time of our measurements. The variability in $\mathrm{Pa}-\mathrm{PETCO} \mathrm{O}_{2}$ coincident with changes in $\mathrm{CI}$ explains the variability in that difference reported by others. ${ }^{3}$ Indeed, when $\mathrm{CI}$ is constant during surgery, the $\mathrm{Pa}-\mathrm{PETCO}_{2}$ difference also remains stable. ${ }^{1}$

The temporal effects of altered $\mathrm{CI}$ on $\mathrm{Pa}$ and $\mathrm{PETCO}_{2}$ in our patients are unknown, but information from the canine model of shock has been published. The inflation and deflation of a balloon placed in the venae cava caused acute decreases and increases in cardiac output respectively and the percent changes in $\mathrm{Pa}$ and $\mathrm{PETCO}_{2}$ were directly related to the percent change in cardiac output. ${ }^{6}$ The maximum change was reached after six to eight breaths (approximately $45 \mathrm{sec}$ ). The major difference between our results and those of the canine study is the $\mathrm{Pa}-\mathrm{PETCO}_{2}$. In our study, the change in $\mathrm{Pa}-\mathrm{PETCO}_{2}$ varied in direction and magnitude, whereas the $\mathrm{Pa}-\mathrm{PETCO}_{2}$ difference in the dogs was inversely related with $\mathrm{CI}$. In the canine study, measurements of $\mathrm{PCO}_{2}$ were made in a quasi-steady state, that is when the changes in $\mathrm{PeTCO}_{2}$ were at their maximum. This was attained within one minute. We can only assume that the changes in dead space ventilation $\left[\left(\mathrm{VD} / \mathrm{VT}_{\mathrm{T}}=\right.\right.$ $\left.\mathrm{PaCO}_{2}-\mathrm{PETCO}_{2} / \mathrm{PaCO}_{2}\right]$, expected with alterations in cardiac output occur shortly after but not coincidently with $\mathrm{CI}$ changes. It has been demonstrated, in dogs, that during a maintained low cardiac output state, the initial reduction in $\mathrm{Pa}$ and $\mathrm{PETCO}_{2}$ is followed by a progressive increase starting less than ten minutes after the acute reduction in cardiac output. ${ }^{6,4}$ This raises the question of whether the effects of alterations of $\mathrm{CI}$ on shunt are also biphasic.

In summary, our results indicate that (1) the magnitude of alterations in $\mathrm{CI}$ can be estimated from a knowledge of the accompanying change in $\mathrm{PETCO}_{2}$ and (2) that the immediate effect of alterations of $\mathrm{CI}$ on $\mathrm{Pa}-\mathrm{PETCO}_{2}$, and hence on VD/VT are variable in magnitude and direction.

\section{Acknowledgement}

We thank our cardiac anaesthesia colleagues for their cooperation, our Respiratory Technologists for their help and Mrs. Sarah Scholl for her secretarial assistance. We also thank Mallinckrodt Medical Inc. (Canada) for their financial support.

\section{References}

1 Sharma SK, McGuire GP, Cruise CJE. Stability of the arterial to end-tidal carbon dioxide difference during anaesthesia for prolonged neuro-surgical procedures. Can J Anaesth 1995; 42: 498-503.

2 Raemer DB, Francis D, Philip JH, Gabel RA. Variations in $\mathrm{PCO}_{2}$ between arterial blood and peak expired gas during anesthesia. Anesth Analg 1983; 62: 1065-9.

3 Shibutani K, Muraoka M, Shirasaki S, Kubal K, Sanchala $V T$, Gupte $P$. Do changes in end-tidal $\mathrm{PCO}_{2}$ quantitatively reflect changes in cardiac output? Anesth Analg 1994; 79: 829-33.

4 Deriaz H, Song Q, Delva E, Lienhart A. Relationship between cardiac output and end-tidal carbon dioxide tension in anesthetized patients. Anesthesiology 1993; 79: A509.

5 Isserles $S A$, Breen $P$. Can changes in end-tidal $\mathrm{PCO}_{2}$ measure changes in cardiac output? Anesth Analg 1991; 73: 808-14.

6 Morimoto Y, Kemmotsu O, Murakami F, Yamamura T, Mayumi T. End-tidal $\mathrm{CO}_{2}$ changes under constant cardiac output during cardiopulmonary resuscitation. Crit Care Med 1993; 21: 1572-6. 